\title{
KARTA POLAKA A PRAWO DO OCHRONY ZDROWIA I DOSTĘP DO ŚWIADCZEŃ OPIEKI ZDROWOTNEJ
}

Karta Polaka jest dokumentem potwierdzającym przynależność do Narodu polskiego. Jednocześnie przyznaje osobie spełniającej przesłanki wynikające z ustawy z dnia 7 września 2007 r. o Karcie Polaka ${ }^{1}$, prawną legitymację do korzystania z wynikających z ustawy uprawnień i przywilejów podczas pobytu w Polsce.

Jednym z uprawnień wynikających z art. 6 u.o.K.P. jest prawo do korzystania ze świadczeń opieki zdrowotnej w stanach nagłych w zakresie określonym w ustawie z dnia 27 sierpnia 2004 r. o świadczeniach opieki zdrowotnej finansowanych ze środków publicznych ${ }^{2}$. Uprawnienie wynikające z art. 19 u.ś.o.z. gwarantuje cudzoziemcom, którzy nie posiadają tytułu do ubezpieczenia zdrowotnego, otrzymanie bezpłatnych świadczeń opieki zdrowotnej, udzielanych niezwłocznie, w stanach nagłego zagrożenia zdrowotnego. Przepis ten koresponduje przede wszystkim z treścią art. 1 ustawy z dnia 8 września 2006 r. o Państwowym Ratownictwie Medycznym $^{3}$, który wskazuje, że to zadaniem państwa jest zapewnianie pomocy każdej osobie znajdującej się w stanie nagłego zagrożenia zdrowotnego. W celu realizacji tego zadania utworzony został system Państwowego Ratownictwa Medycznego, który działa z ramienia państwa.

W rzeczy samej państwo, a w szczególności działający z inicjatywy ustawodawcy system Państwowego Ratownictwa Medycznego, zobowiązane jest do udzielenia pomocy każdej osobie znajdującej się w stanie nagłego zagrożenia zdrowotnego, a posiadanie Karty Polaka nie może być kryterium determinującym

Dr n. med. Monika SADowska - Wyższa Szkoła Inżynierii i Zdrowia w Warszawie; e-mail: monika.b.sadowska@gmail.com

${ }^{1}$ Art. 3 ustawy z dnia 7 września 2007 r. o Karcie Polaka (tekst. jedn.: Dz.U. 2018 r., poz. 1272 ze zm.) [dalej: u.o.K.P.].

${ }^{2}$ Ustawa z dnia 27 sierpnia 2004 r. o świadczeniach opieki zdrowotnej finansowanych ze środków publicznych (tekst jedn.: Dz.U. 2019 r., poz. 1373 ze zm.) [dalej: u.ś.o.z.].

${ }^{3}$ Ustawa z dnia 8 września 2006 r. o Państwowym Ratownictwie Medycznym (tekst jedn.: Dz.U. z 2019 r., poz. 993 ze zm.) [dalej: u.p.r.m.]. 
uzyskanie takiego rodzaju świadczenia. Udzielenie pomocy medycznej ratującej życie człowieka nie może być bowiem uzależnione od spełnienia jakichkolwiek innych przesłanek, niż znajdowanie się w stanie nagłego zagrożenia zdrowotnego, a w związku z tym nie może być uzależnione od wieku, płci, posiadania obywatelstwa polskiego, legalności pobytu cudzoziemca, statusu majątkowego, czy też od faktu podlegania ubezpieczeniu zdrowotnemu.

Prawodawca, określając zasady zapewniania pomocy każdej osobie znajdującej się w stanie nagłego zagrożenia zdrowotnego, realizuje w praktyce konstytucyjną zasadę ochrony zdrowia. Zgodnie z art. 68 ust. 1 i 2 Konstytucji Rzeczypospolitej Polskiej ${ }^{4}$ każdy ma prawo do ochrony zdrowia, a obywatelom - niezależnie od ich sytuacji materialnej - władze publiczne zapewniają równy dostęp do świadczeń opieki zdrowotnej finansowanej ze środków publicznych. Poprzez użycie określenia „każdy" należy rozumieć, że prawo do ochrony zdrowia przysługuje każdemu człowiekowi niezależnie od wieku, płci, wykształcenia, statusu zawodowego czy społecznego, obywatelstwa, wyznania, czy innych kryteriów. Prawo do ochrony zdrowia nie jest prawem nadanym jego adresatom $\mathrm{z}$ woli władzy państwowej. Jest to bowiem prawo podstawowe, wynikające z przyrodzonej i niezbywalnej godności człowieka, którą władza państwowa ma obowiązek szanować i chronić, zapewnić jej nienaruszalność ${ }^{5}$. Stąd nie może tego prawa nie tylko kwestionować, ale także nie może ograniczać 6 . Należy jednak podkreślić, że prawo do ochrony zdrowia nie jest tożsame z prawem dostępu do świadczeń zdrowotnych, w tym do świadczeń opieki zdrowotnej finansowanej ze środków publicznych. Ochrona zdrowia to przede wszystkim prawo do zachowania życia i jego ochrony, gdy jest ono zagrożone ${ }^{7}$. Natomiast dostęp do świadczeń opieki zdrowotnej umożliwia realizację tego prawa. Można rzec, że jest swojego rodzaju narzędziem. Na powszechną dostępność składa się:

- dostępność fizyczna - świadczenia zdrowotne muszą znajdować się w „fizycznym zasięgu" wszystkich uprawnionych;

- dostępność ekonomiczna, czyli osiągalność po przestępnej cenie, oferowania świadczenia, na które każdy może sobie pozwolić;

- dostępność informacji, czyli prawo do poszukiwania i otrzymywania, a także przekazywania informacji związanych ze zdrowiem ${ }^{8}$.

${ }^{4}$ Konstytucja Rzeczypospolitej Polskiej z dnia 2 kwietnia 1997 r. (Dz.U. z 1997 r., Nr 78, poz. 483 ze zm.).

${ }^{5}$ Stosownie do postanowień art. 30 Konstytucji RP „,przyrodzona i niezbywalna godność człowieka stanowi źródło wolności i praw człowieka i obywatela. Jest ona nienaruszalna, a jej poszanowanie i ochrona jest obowiązkiem władz publicznych".

${ }^{6}$ Wyrok Trybunału Konstytucyjnego z dnia 15 listopada 2000 r., P 12/99, OTK 2000, nr 7, poz. 206.

${ }^{7}$ Wyrok Trybunału Konstytucyjnego z dnia 7 stycznia 2004 r., K 14/03, Legalis nr 60760.

8 W. Galewicz, Zdrowie jako prawo czlowieka, „Diametros” 2014, nr 42, s. 70. 
Należy przy tym mieć na uwadze stanowisko Trybunału Konstytucyjnego, którego zdaniem, w zakresie dostępności do świadczeń opieki zdrowotnej finansowanych ze środków publicznych nie chodzi o dostępność jedynie formalną, deklarowaną przez przepisy prawne o charakterze „programowym”, ale o dostępność rzeczywistą, stanowiącą realizację konstytucyjnego prawa do ochrony zdrowia9

$\mathrm{Z}$ treści art. 68 Konstytucji RP należałoby wyprowadzić wniosek, że prawo to przysługuje w zakresie ochrony zdrowia każdemu człowiekowi, natomiast w zakresie dostępu do świadczeń opieki zdrowotnej finansowanej ze środków publicznych - „obywatelom”. Doprecyzowanie tego prawa w drodze ustaw należy zatem do ustawodawcy. S. Jarosz-Żukowska zwraca uwagę, że posłużenie się w art. 68 ust. 2 Konstytucji RP terminem „obywatel” bez użycia przymiotnika „polski”, należy rozumieć jako wolę pozostawienia ustawodawcy możliwości rozszerzenia zakresu podmiotowego prawa do świadczeń zdrowotnych finansowanych ze środków publicznych, także na niektóre kategorie cudzoziemców, czemu prawodawca dał wyraz obowiązującej ustawie o świadczeniach opieki zdrowotnej finansowanej ze środków publicznych, rozszerzając jej zakres podmiotowy na osoby niebędące obywatelami polskimi.

W świetle powyższego działania ratownicze powinny być podejmowane wobec każdej osoby, której życie lub zdrowie jest zagrożone wskutek wystąpienia nagłego niebezpieczeństwa. Nikt nie może być wykluczony, gdy chodzi o udzielenie mu pomocy w stanach nagłego zagrożenia zdrowotnego. Co więcej, pomoc taka powinna być udzielona każdej osobie przebywającej na terytorium Państwa Polskiego, legalnie lub nawet nielegalnie, i powinna być udzielona bezpłatnie.

Nie można pominąć, że art. 19 u.ś.o.z. koresponduje także z treścią art. 15 ustawy z dnia 15 kwietnia 2011 r. o działalności leczniczej ${ }^{10}$, który stanowi, że podmiot leczniczy nie może odmówić udzielenia świadczenia zdrowotnego osobie, która potrzebuje natychmiastowego udzielenia takiego świadczenia ze względu na zagrożenie życia lub zdrowia. Obowiązek ten ma charakter bezwzględny i wyprzedza ograniczenia wynikające $z$ umów o świadczenia opieki zdrowotnej finansowanych ze środków publicznych ${ }^{11}$. W przypadkach nagłych pacjentowi należy udzielić świadczenia zdrowotnego poza kolejnością.

Obowiązek niezwłocznego udzielania świadczeń opieki zdrowotnej w stanach nagłych wynikający z art. 19 u.ś.o.z. jest także spójny z normami wyrażonymi w ustawach zawodowych regulujących wykonywanie zawodów lekarza, pielęgniar-

9 Tamże.

${ }^{10}$ Ustawa z dnia 15 kwietnia 2011 r. o działalności leczniczej (tekst jedn.: Dz.U. z 2018 r., poz. 2190 ze zm.) [dalej: u.d.1.].

11 Wyrok Sądu Najwyższego z dnia 3 listopada 2004 r., III CK 546/03, LEX nr 182096. 
ki i położnej, ratownika medycznego oraz normami deontologicznymi wynikającymi z kodeksów etyki zawodowej wskazanych zawodów medycznych. Stosownie do postanowień art. 30 ustawy z dnia 5 grudnia 1996 r. o zawodzie lekarza i lekarza dentysty $^{12}$, lekarz ma obowiązek udzielać pomocy lekarskiej w każdym przypadku, gdy zwłoka w jej udzieleniu mogłaby spowodować niebezpieczeństwo utraty życia, ciężkiego uszkodzenia ciała lub ciężkiego rozstroju zdrowia, oraz w innych przypadkach niecierpiących zwłoki. Obowiązek ten dotyczy każdego lekarza niezależnie od aktualnego zatrudnienia lub jego braku oraz bez względu na to, czy jest w trakcie wykonywania obowiązków zawodowych, czy też spędza czas wolny ${ }^{13}$.

Pielęgniarka i położna także są obowiązane, zgodnie z posiadanymi kwalifikacjami zawodowymi, do udzielania pomocy w każdym przypadku, gdy zwłoka w jej udzielaniu mogłaby spowodować stan nagłego zagrożenia zdrowotnego (art. 12 ustawy z dnia 15 lipca 2011 o zawodach pielęgniarki i położnej ${ }^{14}$ ). Nakaz ten jest bezwzględny i dotyczy każdej osoby wykonującej zawód pielęgniarki lub położnej ${ }^{15}$.

Zawodem, który w swojej profesji poprzez zakres zadań i obowiązków sprowadza się przede wszystkim do ratowania ludzkiego życia, jest zawód ratownika medycznego. Osoba go wykonująca ma obowiązek postępowania zgodnie ze wskazaniami aktualnej wiedzy medycznej oraz z należytą starannością (art. 11 ust. 3 u.p.r.m.).

Należy zwrócić uwagę, że lekarz, pielęgniarka, położna, ratownik medyczny nie mają prawa jako osoby zobowiązane odmówić udzielenia pomocy ze względu na niebezpieczeństwo osobiste. Jest to bardzo wąskie ujęcie klauzuli bezpieczeństwa, która pozwala na zaniechanie udzielenia pomocy wyłącznie w przypadku, gdy osobom tym grożą najpoważniejsze skutki (utrata życia, ciężki uszczerbek na zdrowiu) spowodowane czynnikami zdrowotnymi, a nie stanem zdrowia pacjenta ${ }^{16}$.

Wskazane przepisy prawa wprowadzają niepodważalny ustawowy nakaz skierowany do osób wykonujących zawód medyczny oraz do wszystkich zakładów leczniczych udzielenia pomocy osobie znajdującej się w stanie nagłym. Wobec po-

${ }^{12}$ Ustawa z dnia 5 grudnia 1996 r. o zawodzie lekarza i lekarza dentysty (tekst jedn.: Dz.U. z 2019 r., poz. 537 ze zm.) [dalej: u.z.1.].

${ }^{13}$ E. ZIELIŃsKa, Uwaga 1 do art. 30, [w:] Ustawa z dnia 5 grudnia 1996 r. o zawodach lekarza i lekarza dentysty. Komentarz, red. E. Zielińska, Warszawa 2014, s. 554.

${ }^{14}$ Ustawa z dnia 15 lipca 2011 o zawodach pielęgniarki i położnej (tekst jedn.: Dz.U. z 2019 r., poz. 576 ze zm.) [dalej: u.z.p.p.].

15 M. Sadowska, Komentarz do art. 12, [w:] Ustawa o zawodach pielęgniarki i położnej. Komentarz, red. M. Sadowska, W. Lis, Warszawa 2019, s. 90.

${ }^{16}$ M. Sadowska, Komentarz do art. 12, s. 91; D. Karkowska, Prawo medyczne dla pielegniarek, Warszawa 2013, s. 133; E. ZielińsKA, Uwaga 1 do art. 30, s. 564. 
wyższego ani szpital, ani żaden inny podmiot wykonujący działalność leczniczą nie może odmówić osobie świadczenia zdrowotnego, jeżeli osoba taka potrzebuje natychmiastowego udzielenia takiego świadczenia ze względu na nagłe zagrożenie życia lub zdrowia. Naruszenie obowiązku udzielenia pomocy przez osobę wykonującą zawód medyczny czy nieudzielenie przez podmiot leczniczy świadczenia zdrowotnego osobie w stanie zagrożenia życia lub zdrowia skutkuje odpowiedzialnością prawną.

Nie bez znaczenia w tej kwestii pozostają zasady etyki lekarskiej, pielęgniarki i położnej oraz ratownika medycznego, które zobowiązują te osoby do przestrzegania najwyższego nakazu etycznego, jakim jest działanie na rzecz dobra chorego. Powołaniem lekarza jest ochrona życia i zdrowia ludzkiego, zapobieganie chorobom, leczenie chorych oraz niesienie ulgi w cierpieniu; lekarz nie może posługiwać się wiedzą i umiejętnością lekarską w działaniach sprzecznych z tym powołaniem (art. 2 ust. 1 Kodeksu Etyki Lekarskiej ${ }^{17}$ ). Normy etyczne wyrażone w Kodeksie Etyki Zawodowej Pielęgniarki i Położnej Rzeczypospolitej Polskiej ${ }^{18} \mathrm{w}$ treści przyrzeczenia nakazują pielęgniarce i położnej sprawować profesjonalną opiekę nad życiem i zdrowiem ludzkim (pkt 1) oraz nieść pomoc każdemu człowiekowi bez względu na rasę, wyznanie religijne, narodowość, poglądy polityczne, stan majątkowy i inne różnice (pkt 3). Normy deontologiczne nakazują przedstawicielom obu profesji podejmowanie działań leżących w interesie pacjentów, szczególnie w razie zagrożenia ich życia i zdrowia (Część ogólna, pkt 6).

Podobnie ratownik medyczny zobowiązany jest do podejmowania medycznych czynności ratunkowych z najwyższą starannością zawodową wobec każdej osoby znajdującej się w sytuacji zagrożenia życia i zdrowia ${ }^{19}$.

Wprawdzie kodeksy etyki zawodowej nie są źródłem prawa, jednakże zawarte w nich normy deontologiczne w znaczny sposób wzmacniają system prawa pozytywnego w obszarze ochrony zdrowia, doprecyzowując i uzupełniając przepisy rangi ustawowej. Należy zgodzić się z L. Bartkowiakiem i T. Maksymiukiem, że „nie wszystkie zawody mają i nie wszystkie zawody powinny mieć kodeksy swojej zawodowej etyki. Mianowicie, potrzeba jej tam, gdzie w grę wchodzą i mogą być narażone najważniejsze wartości moralne, takie jak: życie, zdrowie, autonomia

${ }^{17}$ Kodeks Etyki Lekarskiej, https://www.nil.org.pl/_data/assets/pdf_file/0003/4764/Kodeks-Etyki-Lekarskiej.pdf [dostęp: 6.08.2019].

${ }^{18}$ Kodeks Etyki Zawodowej Pielęgniarki i Położnej Rzeczypospolitej Polskiej, https://nipip.pl/ prawo/samorzadowe/krajowy-zjazd-pielegniarek-i-poloznych/kodeks-etyki-zawodowej-pielegniarki-i-poloznej-rzeczypospolitej-polskiej/

${ }_{19}$ K. Wnukowski, Z. KopaŃski, G. Sianos, Specyfika pracy ratownika medycznego, „Journal of Clinical Helathcare” 2015, nr 3, s. 7; R. BraczKowski, P. Rams, Ł. Styś, Problemy prawne i etyczne w zawodzie ratownika medycznego, „Ostry Dyżur” 2010, nr 1, s. 17. 
człowieka, bezpieczeństwo, zaufanie" ${ }^{20}$. Z takimi wartościami stykamy się w obszarze opieki zdrowotnej, co uzasadnia sprawowanie „pieczy” nad wykonywaniem zawodów medycznych przez samorządy zawodowe w granicach interesu publicznego i dla jego ochrony ${ }^{21}$.

Wracając do meritum, osoby posiadające Kartę Polaka uprawnione są do korzystania ze świadczeń opieki zdrowotnej w stanach nagłych. Za stan „nagły” w rozumieniu art. 19 ust. 1 u.ś.o.z. należy uznać nie tylko zdarzenia wymagające bezpośredniej i natychmiastowej ingerencji podmiotu leczniczego, ale również takie, co do których nie było możliwe ich odłożenie w czasie bez ciężkich skutków dla życia i zdrowia ludzkiego. Z kolei, zgodnie z art. 3 pkt 8 u.p.r.m. stan nagłego zagrożenia zdrowotnego to stan polegający na nagłym lub przewidywanym w krótkim czasie pojawieniu się objawów pogarszania zdrowia, którego bezpośrednim następstwem może być poważne uszkodzenie funkcji organizmu lub uszkodzenie ciała, lub utrata życia, wymagający podjęcia natychmiastowych medycznych czynności ratunkowych i leczenia.

Z praktycznego punktu widzenia przywołane rozbieżności terminologiczne wynikające $\mathrm{z}$ różnych ustaw, niewątpliwie prowadzą do daleko idącego utrudnienia interpretacyjnego, co przekłada się na realizację prawa dostępu do świadczeń zdrowotnych finansowanych ze środków publicznych. Pomocne w tym względzie jest stanowisko Sądu Najwyższego ${ }^{22}$, który stwierdził, że świadczeniami opieki zdrowotnej udzielanymi w stanach zagrożenia życia objęte zostały w zasadzie stany nagłe i niespodziewane, których nie można przewidzieć (np. pacjenci z udarem mózgu, zawałem serca, poszkodowani w wypadkach drogowych). Nie są nimi zabiegi, które wprawdzie ratują życie, jednak stosowane są u chorych leczonych przewlekle, wymagających regularnego poddawania się zabiegom medycznym. Z kolei Naczelny Sąd Administracyjny ${ }^{23}$ uznał, że pojęcie stanu nagłego obejmuje swoim zakresem pomoc lekarską, która ma zapobiec ciężkim (poważnym) skutkom. Mianowicie chodzi o przypadek, w odniesieniu do którego istnieje niemożność (przeciwwskazanie) odłożenia (przesunięcia) w czasie pomocy lekarskiej, mogącej według wiedzy i doświadczenia medycznego zapobiec powstaniu u pa-

${ }^{20}$ L. BartKowiak, T. Maksymiuk, Budowa i funkcje kodeksu etyki zawodowej na przykladzie Kodeksu etyki lekarskiej, „Medyczna Wokanda” 2018, nr 11, s. 36.

${ }^{21}$ Stosownie do postanowień art. 17 ust. 1 Konstytucji RP: „w drodze ustawy można tworzyć samorządy zawodowe, reprezentujące osoby wykonujące zawody zaufania publicznego i sprawujące pieczę nad należytym wykonywaniem tych zawodów w granicach interesu publicznego i dla jego ochrony".

${ }^{22}$ Wyrok Sądu Najwyższego z dnia 4 stycznia 2007 r., V CSK 396/2006, LexPolonica nr 1394730.

${ }^{23}$ Wyrok Naczelnego Sądu Administracyjnego z dnia 3 października 2012 r., II GSK 1369/11, LEX nr 1233974. 
cjenta niekorzystnych skutków (zagrożenia) dla jego życia i zdrowia. W kontekście ziszczenia się przesłanek realizacji świadczenia w trybie określonym w art. 19 ust. 1 u.ś.o.z. istotne znaczenie ma więc „natychmiastowość” i „bezpośredniość” zagrożenia, które uzasadniają niezwłoczne udzielenie pomocy poprzez natychmiastowe udzielenie świadczenia.

Natomiast Wojewódzki Sąd Administracyjny w Warszawie ${ }^{24}$ stwierdził, że skoro w stanach nagłych świadczenia zdrowotne są udzielane bez wymaganego skierowania, to termin ,nagły” nie może być rozumiany inaczej, niż określa to definicja legalna wyrażona w art. 3 pkt 1 u.p.r.m. Tym samym w ocenie Sądu, sam fakt przyjęcia pacjenta do szpitala bez skierowania od właściwego lekarza, z pominięciem procedury ustalania kolejności dostępu do świadczeń zdrowotnych $^{25}$ określonej w art. 20 ust. 1 i 2 u.ś.o.z. oznacza, że pacjent znajduje się w stanie, w którym odmówienie pomocy medycznej może skutkować utratą zdrowia lub życia, a więc w stanie nagłym, wymagającym niezwłocznego udzielenia świadczenia.

Nie można jednak wykluczyć sytuacji, w której pacjent zgłasza się do podmiotu leczniczego z powodu subiektywnego odczucia zagrożenia dla życia lub zdrowia, domagając się udzielenia świadczenia zdrowotnego. Tym samym, udzielenie świadczenia zdrowotnego może okazać się nieuzasadnione w kategoriach kwalifikacji do uprawnień skorzystania ze świadczeń w stanach nagłego zagrożenia zdrowotnego, na co zwraca uwagę Sąd Najwyższy ${ }^{26}$ w kontekście nieograniczonego zwiększania kosztów opieki zdrowotnej. Stąd dla oceny, czy w danym przypadku zachodzi potrzeba natychmiastowego udzielenia świadczenia zdrowotnego ze względu na stan zdrowia pacjenta, należy stosować kryteria obiektywne. Wbrew pozorom, ocena stanu zdrowia w obrębie jednostki ratownictwa medycznego nie jest sprawą łatwą, co niejednokrotnie jest uwarunkowane istotą choroby i procedurą jej diagnozowania. Niejednokrotnie celem rozpoznania jednostki chorobo-

${ }^{24}$ Wyrok Wojewódzkiego Sądu Administracyjnego w Warszawie z dnia 17 listopada 2005 r., VI SA/Wa 1003/2005.

${ }^{25}$ Stosownie do postanowień art. 20 ust. 1 ustawy z dnia 27 sierpnia 2004 r. o świadczeniach opieki zdrowotnej finansowanych ze środków publicznych (tekst jedn.: Dz.U. 2019 r., poz. 1373 ze zm.): „świadczenia opieki zdrowotnej w szpitalach i świadczenia specjalistyczne w ambulatoryjnej opiece zdrowotnej są udzielane według kolejności zgłoszenia $\mathrm{w}$ dniach i godzinach ich udzielania przez świadczeniodawcę, który zawarł umowę o udzielanie świadczeń opieki zdrowotnej”. W celu zapewnienia dostępu do świadczeń opieki zdrowotnej wprowadzono ustawowe uregulowanie zasady dostępu do świadczeń planowych, polegające na prowadzeniu przez świadczeniodawców list osób oczekujących na świadczenia z zapewnieniem pełnej, jawnej informacji o możliwości udzielenia świadczenia i czasie oczekiwania, a także o możliwości skorzystania ze świadczenia zdrowotnego u innego świadczeniodawcy.

${ }^{26}$ Wyrok Sądu Najwyższego z 15 listopada 2003 r., IV CK 189/2002, LexPolonica nr 1632215. 
wej należy przeprowadzić diagnostykę różnicową ${ }^{27}$, której wyniki potwierdzą lub wykluczą stan zagrożenia życia. Dla przykładu można wskazać postępowanie w ostrych zespołach wieńcowych wymagające wykonania oprócz badania EKG, także badań laboratoryjnych, tzw. panelu kardiologicznego polegającego m.in. na oznaczeniu wartości troponiny w odstępach kilkugodzinnych, czy też diagnostyka nagłego, ostrego bólu brzucha wymagająca niejednokrotnie oprócz diagnostyki laboratoryjnej, także badań obrazowych, w tym wysoce specjalistycznych (np. tomografia komputerowa). Dlatego też ocena, czy konkretna osoba znajduje się w stanie nagłego zagrożenia zdrowotnego niejednokrotnie jest możliwa po przeprowadzeniu badań, których wyniki mogą wykluczyć stan zagrożenia życia lub zdrowia. Nie oznacza to jednak, że taką osobę można obciążyć opłatą za przeprowadzone medyczne czynności ratunkowe w sytuacji braku ubezpieczenia, bowiem podstawą do wdrożenia procedur diagnostycznych jest stan zdrowia pacjenta w chwili przyjęcia do podmiotu leczniczego lub zawiadomienia zespołu ratownictwa medycznego, a nie epikryza ${ }^{28}$.

Medycznymi czynnościami ratunkowymi nazywa się świadczenia opieki zdrowotnej, które udzielane są przez zespół ratownictwa medycznego, w tym lotniczy zespół ratownictwa medycznego, w warunkach pozaszpitalnych w celu ratowania osoby w stanie nagłego zagrożenia medycznego (art. 3 pkt 4 p.r.m.). Świadczenia zdrowotne niezbędne dla ratownictwa medycznego udzielane są również w zakresie szpitalnego oddziału ratunkowego (dalej: SOR), centrum urazowego, centrum urazowego dla dzieci lub jednostki szpitala wyspecjalizowanej w udzielaniu świadczeń zwrotnych niezbędnych dla ratownictwa medycznego, w tym niezbędnego transportu sanitarnego osoby w stanie nagłego zagrożenia zdrowotnego do najbliższego zakładu leczniczego podmiotu leczniczego udzielającego świadczeń opieki zdrowotnej w odpowiednim zakresie (art. 33 ust. 1 i 2 p.r.m.). Zgodnie z $§ 2$ rozporządzenia Ministra Zdrowia z dnia 27 czerwca 2019 r. w sprawie szpitalnego oddziału ratunkowego ${ }^{29}$, SOR udziela świadczeń opieki zdrowotnej polegających na wstępnej diagnostyce oraz podjęciu leczenia w zakresie niezbędnym

${ }^{27}$ Istotą procesu diagnostyki różnicowej jest ocena prawdopodobieństwa, że dany objaw kliniczny (dana grupa objawów klinicznych) występuje w odnośnej chorobie. Stopniowo eliminuje się hipotezy najmniej prawdopodobne i w miarę potrzeby zleca nowe badania. Procedura ta trwa do momentu postawienia najbardziej prawdopodobnej diagnozy (F. Кокот, Diagnostyka różnicowa objawów chorobowych, Warszawa 2005).

${ }^{28}$ Epikryza - termin medyczny, służący do określenia analizy postępowania lekarskiego, wydawanego po zakończeniu całego postępowania z chorym na wszystkich etapach procesu diagnostyczno-leczniczego.

${ }^{29}$ Rozporządzenie Ministra Zdrowia z dnia 27 czerwca 2019 r. w sprawie szpitalnego oddziału ratunkowego (Dz.U. z 2019 r., poz. 1213) [dalej: r.s.o.r.]. 
dla stabilizacji funkcji życiowych osób, które znajdują się w stanie nagłego zagrożenia zdrowotnego. W skład oddziału wchodzi m.in. obszar segregacji medycznej, w którym ustala się kolejność udzielania świadczeń opieki zdrowotnej realizowany wobec osób w stanie nagłego zagrożenia zdrowotnego, uwzględniający stan zdrowia tych osób.

Segregację przeprowadza pielęgniarka systemu, ratownik medyczny lub lekarz systemu ${ }^{30}$.

Osoby te dokonują oceny stanu zdrowia pacjenta pod względem ustalenia priorytetu udzielania im świadczeń zdrowotnych i przydzielenia ich do jednej z kategorii pilności w pięciostopniowej skali oznaczonej odpowiednim kolorem. W kolejności są to:

1) kolor czerwony oznacza natychmiastowy kontakt z lekarzem;

2) kolor pomarańczowy - czas oczekiwania na pierwszy kontakt z lekarzem do 10 minut;

3) kolor żółty - czas oczekiwania na pierwszy kontakt z lekarzem do 60 minut;

4) kolor zielony - czas oczekiwania na pierwszy kontakt z lekarzem do $120 \mathrm{mi}$ nut;

5) kolor niebieski - czas oczekiwania na pierwszy kontakt z lekarzem do 240 minut.

Zgodnie z $§ 6$ ust. 11 r.s.o.r. osoby, które zostały przydzielone do kategorii pilności oznaczonej kolorem zielonym lub niebieskim, mogą być kierowane z od-

${ }^{30}$ Zgodnie z definicją wynikającą z art. 3 u.p.r.m., pielęgniarka systemu to pielęgniarka posiadająca tytuł specjalisty lub specjalizująca się w dziedzinie pielęgniarstwa ratunkowego, anestezjologii i intensywnej opieki, chirurgii, kardiologii, pediatrii, a także pielęgniarka posiadająca ukończony kurs kwalifikacyjny w dziedzinie pielęgniarstwa ratunkowego, anestezjologii i intensywnej opieki, chirurgii, kardiologii, pediatrii oraz posiadająca co najmniej 3-letni staż pracy w oddziałach tych specjalności, oddziałach pomocy doraźnej, izbach przyjęć lub pogotowiu ratunkowym; lekarz systemu to: a) lekarz posiadający specjalizację lub tytuł specjalisty w dziedzinie: anestezjologii i intensywnej terapii, medycyny ratunkowej lub neurologii, albo lekarz po drugim roku specjalizacji w tej dziedzinie, który kontynuuje szkolenie specjalizacyjne, lub b) lekarz posiadający specjalizację lub tytuł specjalisty w dziedzinie: chorób wewnętrznych, kardiologii, chirurgii ogólnej, chirurgii dziecięcej, ortopedii i traumatologii narządu ruchu, ortopedii i traumatologii lub pediatrii, lub c) lekarz, który w ramach szkolenia specjalizacyjnego ukończył moduł podstawowy w dziedzinie: chorób wewnętrznych, pediatrii lub chirurgii ogólnej i kontynuuje lub zakończył szkolenie specjalizacyjne oraz uzyskał tytuł specjalisty.

Do dnia 31 grudnia 2020 r. lekarzem systemu może być lekarz posiadający 3000 godzin w wykonywaniu zawodu lekarza w szpitalnym oddziale ratunkowym, zespole ratownictwa medycznego, lotniczym zespole ratownictwa medycznego lub izbie przyjęć szpitala, przy czym lekarz ten jest obowiązany rozpocząc szkolenie specjalizacyjne w dziedzinie medycyny ratunkowej do dnia 1 stycznia 2018 r. W przypadku niespełnienia tego wymogu, lekarz przestaje być lekarzem systemu (art. 57 u.p.r.m.). 
działu do miejsc udzielania świadczeń zdrowotnych z zakresu podstawowej opieki zdrowotnej. Tym samym, zasygnalizowana $\mathrm{w}$ niniejszym opracowaniu problematyka nieuzasadnionego udzielania świadczeń zdrowotnych w sytuacji subiektywnego odczucia zagrożenia dla życia lub zdrowia została najwyraźniej dostrzeżona przez prawodawcę. W jakim stopniu rozwiązanie to będzie zapewniało bezpieczeństwo zdrowotne beneficjentów świadczeń, niewątpliwe zweryfikuje praktyka.

Przepisy polskiego prawa nie przewidują finansowania świadczeń opieki zdrowotnej związanych z ciążą, porodem i połogiem kobietom posiadającym Kartę Polaka. Niemniej w przypadku nagłego zagrożenia zdrowotnego, które może mieć związek z ciążą (np. pęknięcie ciąży ekotopowej) lub porodem (np. gwałtownie postępujący poród; atonia macicy $\mathrm{w}$ okresie porodu odbytego $\mathrm{w}$ warunkach domowych), kobieta powinna być uprawniona do korzystania ze świadczeń opieki zdrowotnej finansowanej ze środków publicznych.

Karta Polaka jest dokumentem potwierdzającym przynależność do Narodu Polskiego, ale nie jest dokumentem tożsamości. Zgodnie z art. 18 ust. 3 u.o.K.P. korzystanie z uprawnień do świadczeń opieki zdrowotnej wymaga okazywania Karty Polaka oraz ważnego dokumentu potwierdzającego tożsamość jej posiadacza. W przypadku cudzoziemca, który nie ma innego tytułu ubezpieczenia, legitymującego się Kartą Polaka, będzie to paszport, którego numer stanowi jednocześnie identyfikator osoby, której udzielono świadczenia w rozumieniu rozporządzenia Ministra Zdrowia z dnia 26 czerwca 2019 r. w sprawie niezbędnych informacji przetwarzanych przez świadczeniodawców, szczegółowego sposobu rejestrowania tych informacji oraz ich przekazywania podmiotom zobowiązanym do finansowania świadczeń ze środków publicznych ${ }^{31}$, który świadczeniodawca jest obowiązany przekazać do Narodowego Funduszu Zdrowia identyfikując wykonane świadczenie (§ 3 i 4 r.n.i.).

Pomiędzy prawem do ochrony zdrowia a prawem dostępu do świadczeń zdrowotnych występuje ścisłe powiązanie. Niewątpliwie prawodawca zagwarantował osobom posiadającym Kartę Polaka otrzymanie bezpłatnych świadczeń opieki zdrowotnej, udzielnych niezwłocznie w stanach zagrożenia życia. Jednocześnie wprowadzając regulację w zakresie systemu ratownictwa medycznego, dołożył starań do zapewnienia bezpiecznych warunków udzielania świadczeń, z poszanowaniem równego traktowania pacjentów w dostępie do świadczeń opieki zdrowot-

${ }^{31}$ Rozporządzenie Ministra Zdrowia z dnia 26 czerwca 2019 r. w sprawie zakresu niezbędnych informacji przetwarzanych przez świadczeniodawców, szczegółowego sposobu rejestrowania tych informacji oraz ich przekazywania podmiotom zobowiązanym do finansowania świadczeń ze środków publicznych (Dz.U. z 2019 r., poz. 1207) [dalej r.n.i.]. 
nej, niezależnie od narodowości, posiadanego obywatelstwa czy legalności pobytu na terytorium Rzeczypospolitej Polskiej.

Niemniej należałoby się zastanowić, czy to uprawnienie nadane przez ustawodawcę w rzeczy samej jest czymś szczególnym, skoro prawo do zachowania życia i jego ochrony w sytuacji zagrożenia nie może w żaden sposób podlegać ograniczeniu, a prawodawca jest obowiązany to prawo uszanować. Tym samym udzielenie pomocy medycznej ratującej życie człowieka nie może być uzależnione od faktu posiadania Karty Polaka, a wyłącznie od stanu zdrowia.

Natomiast zauważalny jest brak regulacji w zakresie świadczeń opieki zdrowotnej udzielanych w związku z ciążą, porodem i połogiem. Wprawdzie, co do zasady, są to stany fizjologiczne, ale niejednokrotnie ich przebieg może być na tyle powikłany, że będzie zagrażał życiu matki i dziecka. W takich sytuacjach winien się uaktualniać obowiązek niezwłocznego udzielania świadczeń opieki zdrowotnej w stanach nagłych finansowanej ze środków publicznych, zwłaszcza że polski ustawodawca nadał zadaniom z zakresu opieki nad kobietą ciężarną szczególny priorytet.

\section{BIBLIOGRAFIA}

\section{Literatura}

BARTKOWIAK L., MAKSYMIUK, T., Budowa i funkcje kodeksu etyki zawodowej na przykładzie Kodeksu etyki lekarskiej, „Medyczna Wokanda” 2018, nr 11.

BraczKowski B., Rams P., Styś Ł., Problemy prawne i etyczne w zawodzie ratownika medycznego, „Ostry Dyżur” 2010, nr 1.

GALEWICZ W., Zdrowie jako prawo człowieka, „Diametros” 2014, nr 42.

KARKowsKa D., Prawo medyczne dla pielęgniarek, Warszawa: Wolters Kluwer Polska 2013.

Ustawa o zawodach lekarza i lekarza dentysty. Komentarz, red. E. Zielińska, Warszawa 2014.

Ustawa o zawodach pielęgniarki i położnej. Komentarz, red. M. Sadowska, W. Lis, Warszawa: Wolters Kluwer Polska 2019.

WNUKOWSKi K., KoPAŃSKi Z., SiAnOs G., Specyfika pracy ratownika medycznego, ,Journal of Clinical Helathcare" 2015, nr 3.

\section{Akty prawne}

Konstytucja Rzeczypospolitej Polskiej z dnia 2 kwietnia 1997 r. (Dz.U. z 1997 r., Nr 78, poz. 483 ze zm.).

Ustawa z dnia 27 sierpnia 2004 r. o świadczeniach opieki zdrowotnej finansowanych ze środków publicznych (tekst jedn.: Dz.U. 2019 r., poz. 1373 ze zm.).

Ustawa z dnia 8 września 2006 r. o Państwowym Ratownictwie Medycznym (tekst jedn.: Dz.U. z 2019 r., poz. 993 ze zm.) 
Ustawa z dnia 7 września 2007 r. o Karcie Polaka (tekst jedn.: Dz.U. 2018 r., poz. 1272 ze zm.).

Ustawa z dnia 5 grudnia 1996 r. o zawodach lekarza i lekarza dentysty (tekst jedn.: Dz.U. z 2019 r., poz. 537 ze zm.).

Ustawa z dnia 15 kwietnia 2011 r. o działalności leczniczej (tekst jedn.: Dz.U. z 2018 r., poz. 2190 ze zm.).

Ustawa z dnia 15 lipca 2011 o zawodach pielęgniarki i położnej (tekst jedn.: Dz.U. z 2019 r., poz. $576 \mathrm{ze} \mathrm{zm}$.).

Rozporządzenie Ministra Zdrowia z dnia 26 czerwca 2019 r. w sprawie zakresu niezbędnych informacji przetwarzanych przez świadczeniodawców, szczegółowego sposobu rejestrowania tych informacji oraz ich przekazywania podmiotom zobowiązanym do finansowania świadczeń ze środków publicznych (Dz.U. z 2019 r., poz. 1207).

Rozporządzenie Ministra Zdrowia z dnia 27 czerwca 2019 r. w sprawie szpitalnego oddziału ratunkowego (Dz.U. z 2019 r., poz. 1213).

\section{Orzecznictwo}

Wyrok Trybunału Konstytucyjnego z dnia 15 listopada 2000 r., P 12/99, OTK 2000, nr 7 , poz. 206.

Wyrok Trybunału Konstytucyjnego z dnia 7 stycznia 2004 r., K 14/03, Legalis nr 60760.

Wyrok Sądu Najwyższego z 15 listopada 2003 r., IV CK 189/2002, LexPolonica nr 1632215. Wyrok Sądu Najwyższego z dnia 3 listopada 2004 r., III CK 546/03, LEX nr 182096.

Wyrok Sądu Najwyższego z dnia 4 stycznia 2007 r., V CSK 396/2006, LexPolonica nr 1394730.

Wyrok Naczelnego Sądu Administracyjnego z dnia 3 października 2012 r., II GSK 1369/11, LEX nr 1233974.

Wyrok Wojewódzkiego Sądu Administracyjnego w Warszawie z dnia 17 listopada 2005 r., VI SA/Wa 1003/2005.

Karta Polaka a prawo do ochrony zdrowia i dostęp do świadczeń opieki zdrowotnej.

\section{KARTA POLAKA A PRAWO DO OCHRONY ZDROWIA I DOSTĘP DO ŚWIADCZEŃ OPIEKI ZDROWOTNEJ}

\section{Streszczenie}

Karta Polaka jest dokumentem potwierdzającym przynależność do Narodu polskiego. Jednocześnie przyznaje jej posiadaczowi określone uprawnienia i przywileje, z których może korzystać podczas pobytu w Polsce. Obowiązujące przepisy prawa uprawniają posiadaczy Karty Polaka między innymi do korzystania $\mathrm{z}$ bezpłatnych świadczeń opieki zdrowotnej, udzielanych niezwłocznie, w stanach nagłego zagrożenia zdrowotnego. Tym samym ustawodawca realizuje w praktyce konstytucyjną zasadę ochrony zdrowia, rozumianej jako prawo do zachowania życia 
i jego ochrony, gdy jest ono zagrożone. Jest to prawo podstawowe, wynikające z przyrodzonej i niezbywalnej godności człowieka, którego nie można kwestionować, a ani w żaden sposób ograniczać.

W niniejszym opracowaniu omówiona zostanie zatem relacja Karty Polaka do problematyki realizacji prawa do ochrony zdrowia i dostępu do świadczeń opieki zdrowotnej, z uwzględnieniem opieki w okresie ciąży i okołoporodowej.

Rozważania zostały oparte na stanie prawnym aktualnym na dzień 16 sierpnia 2019 r.

Słowa kluczowe: Karta Polaka; prawo do ochrony zdrowia; świadczenie zdrowotne; ratownictwo medyczne

\title{
THE POLE'S CARD, THE RIGHT TO HEALTH AND ACCESS TO HEALTH CARE BENEFITS
}

\begin{abstract}
Sum mary
The Pole's Card is a document confirming belonging to the Polish Nation. At the same time, it grants its owner specific rights and privileges that he or she can use during their stay in Poland. The current law entitles holders of the Pole's Card to, among others, benefit from free and immediate healthcare services provided in an emergency. Thus, the legislator implements and puts into practice the constitutional principle of health care, understood as the right to care for a person's life and protecting them when they are threatened. This is a fundamental right that results from man's inherent and inalienable dignity, which cannot be questioned or limited in any way.

This report will, therefore, discuss the relationship of the Pole's Card to the issue of exercising the right to health protection and access to health care services, including pregnancy and perinatal care.
\end{abstract}

The considerations were based on the current legal status as of August 16, 2019.

Key words: Pole's card; right to health protection; health service; Emergency Medical Services 